\title{
PENGARUH MODEL PEMBELAJARAN INKUIRI TERBIMBING (GUIDED INQUIRY) TERHADAP HASIL BELAJAR SISWA PADA MATERI FLUIDA DINAMIS DI KELAS XI SMA SWASTA AL HIDAYAH MEDAN T.P. 2014/2015
}

\author{
Siti Aminah Nainggolan dan Jurubahasa Sinuraya \\ Jurusan Fisika FMIPA Universitas Negeri Medan \\ Jalan Willem Iskandar Pasar V Medan, Sumatera Utara \\ Sitinainggolan69@yahoo.com
}

\begin{abstract}
ABSTRAK
Penelitian ini bertujuan untuk mengetahui pengaruh model pembelajaran inkuiri terbimbing (guided inquiry) terhadap hasil belajar siswa pada materi fluida dinamis. Jenis penelitian ini adalah quasi eksperimen dengan two group Pretest-Posttest Design. Populasi dalam penelitian ini adalah seluruh siswa kelas XI SMA Swasta Al Hidayah Medan T.P.2014/2015 dengan jumlah 3 kelas. Pengambilan sampel dilakukan dengan cara cluster random sampling dengan mengambil 2 kelas dari 3 kelas yaitu kelas XI-1 sebagai kelas eksperimen dan kelas XI-2 sebagai kelas kontrol. Instrumen yang digunakan adalah tes hasil belajar dalam bentuk pilihan berganda sebanyak 20 soal. Teknik analisis data yang digunakan adalah uji beda (uji t), setelah uji prasyarat dilakukan, yaitu uji normalitas dan homogenitas. Hasil penelitian menunjukkan bahwa ada pengaruh yang signifikan model pembelajaran inkuiri terbimbing (guided inquiry) terhadap hasil belajar siswa pada materi fluida dinamis.
\end{abstract}

Kata kunci : model pembelajaran inkuiri terbimbing, hasil belajar fisika

\begin{abstract}
This research is aimed to determine the effect of guided inquiry learning model toward student's learning outcomes in the subject matter of dynamic fluid. The type of this research is a quasi experimental with pretest-posttest control group design. The population in this study were all students of class XI SMA Al Hidayah Private Medan TP 2014/2015 the number 3 class. Sampling was done by cluster random sampling by taking two classes of three gradeare class XI-1 as the experimental class and class XI-2 as the control class. The instrument used are achievement test in the form of 20 multiple-choice questions. The tech of data analyzed is used different test ( $t$-test), after the prerequisite test is done, the test of normality and homogeneity tests. The research showed that there was a significant effect on the guided inquiry learning model outcomes of students in the subject matter of dynamic fluid.
\end{abstract}

Keywords: guided inquiry learning model, study result of physics

\section{INTRODUCTION}

Perkembangan ilmu pengetahuan dan teknologi saat ini sangat mempengaruhi berbagai aspek kehidupan manusia. Bidang pendidikan merupakan salah satu dari aspek tersebut. Bidang pendidikan memegang peranan yang sangat penting dalam kehidupan karena pendidikan merupakan suatu wahana yang digunakan untuk menciptakan sumber daya manusia yang 
berkualitas dan berkompeten di bidangnya. Namun tuntutan tersebut belum terpenuhi.

Masalah utama dalam pembelajaran pada pendidikan (formal) adalah masih rendahnya daya serap peserta didik. Hal ini tampak dari rerata hasil peserta didik yang senantiasa masih sangat memprihatinkan. Berdasarkan data Education For All Global Monitoring Report 2011 yang dikeluarkan oleh UNESCO setiap tahunnya, dan berisi hasil pemantauan pendidikan dunia, dari 127 negara, Education Development Index (EDI) Indonesia berada pada posisi ke-69, dibandingkan Malaysia (65) dan Brunei (34). Penelitian sebelumnya menyatakan bahwa hasil belajar fisika siswa di SMA Swasta Al-Ulum Medan T.P. 2014/2015 lebih dari $60 \%$ belum mencapai KKM (Harahap, 2014: 2). Faktor penyebabnya adalah model dan teknik pembelajaran fisika yang kurang bervariasi dan bersifat teacher centered. Masalah yang sama juga terjadi di SMA Swasta Al Hidayah Medan yang merupakan sekolah yang dijadikan sebagai tempat penelitian. Berdasarkan studi pendahuluan diperoleh informasi bahwa $63 \%$ dari jumlah siswa di kelas XI belum mencapai KKM (Transkip nilai ulangan siswa, 2014). Selanjutnya dari angket yang dibagikan di salah satu kelas XI SMA Swasta Al Hidayah, dari 30 orang siswa hanya $13,3 \%$ menyatakan fisika itu mudah dan menyenangkan, $46 \%$ menyatakan sulit dan kurang menarik. Cara belajar yang sering dilakukan, 83,3\% siswa menyatakan hanya mencatat dan mengerjakan soal. Kemudian untuk belajar yang diinginkan 53,3\% siswa ingin praktikum dan demonstrasi (Angket observasi awal).

Dari permasalahan di atas dapat disimpulkan bahwa faktor-faktor yang mempengaruhi rendahnya aktivitas siswa yang menyebabkan hasil belajar fisika siswa masih rendah adalah model dan teknik pembelajaran Fisika yang kurang bervariasi. Dalam pembelajaran fisika guru lebih dominan menggunakan pembelajaran konvensional yaitu metode ceramah, penugasan, dan pembelajaran sering kali dilakukan satu arah. Lebih lanjut Trianto menyatakan, secara empiris berdasarkan hasil analisis penelitian terhadap rendahnya hasil belajar peserta didik disebabkan dominannya proses pembelajaran konvensional (Trianto, 2010: 5-6). Pada pembelajaran ini suasana kelas cenderung teaher-centered sehingga siswa menjadi pasif.

Merujuk akan masalah tersebut, ada beberapa model pembelajaran yang dapat digunakan untuk mengubah pembelajaran fisika yang bersifat teacher centered menjadi student centered. Salah satunya adalah model pembelajaran inquiry, dalam hal ini adalah inkuiri terbimbing (Guided Inquiry). Alasan penggunaan model pembelajaran inkuiri adalah siswa akan mendapatkan pemahaman-pemahaman yang lebih baik mengenai sains dan akan lebih tertarik terhadap sains jika siswa dilibatkan secara aktif dalam pembelajaran. Hal tersebut dikarenakan fisika adalah pelajaran yang identik dengan eksperimen, sehingga jika siswa diajak secara langsung untuk bereksperimen maka minat siswa terhadap fisika akan bertambah. Dalam hal ini siswa belajar sambil bekerja. Dengan bekerja mereka akan memperoleh pengetahuan, pemahaman, dan aspek-aspek tingkah laku lainnya, serta mengembangkan keterampilan yang bermakna untuk hidup di masyarakat (Hamalik, 2001:172). Dimana menemukan atau membangun informasi merupakan salah satu bagian dari inkuiri terbimbing. Selanjutnya Mayer menyatakan bahwa dalam pembelajaran inkuiri siswa belajar lebih baik ketika mereka aktif, tetapi aktivitas mereka memerlukan bimbingan. Ia juga menambahkan bahwa siswa membutuhkan kebebasan yang cukup dalam proses inkuiri untuk menjadi aktif secara kognitif dalam proses untuk memahami, dan siswa membutuhkan bimbingan yang cukup sehingga hasil dari aktivitas kognitif mereka berdayaguna pengetahuan. Lebih lanjut Suchman mengembangkan pembelajaran inkuiri, dimana berdasarkan hasil penelitiannya model pembelajaran inkuiri menunjukkan bahwa keterampilan 
inkuiri siswa meningkat dan motivasi belajarnya juga meningkat.

Penelitian mengenai model pembelajaran Inkuiri sudah pernah diteliti sebelumnya, dimana hasil penelitian menyatakan bahwa terdapat pengaruh penerapan model inkuiri terbimbing terhadap kemampuan berfikir logis siswa kelas X di SMA Negeri 8 kota Bengkulu (Purwanto, 2013: 249-253). Hasil penelitian lainnya menyimpulkan bahwa hasil belajar siswa dengan menerapkan model pembelajaran inkuiri terbimbing dengan melatihkan keterampilan proses sains dapat meningkatkan hasil belajar (Wahyudi dan Supardi, 2013: 1-8).

Dari beberapa uraian di atas, maka dilakukan penelitian dengan tujuan mengetahui pengaruh model pembelajaran inkuiri terbimbing (Guided Inquiry) terhadap hasil belajar siswa pada materi fluida dinamis di kelas XI SMA Swasta Al Hidayah Medan T.P. 2014/2015.

\section{METODE PENELITIAN}

Jenis penelitian ini adalah quasi eksperiment dengan desain two group Pretest-Posttest Design. Penelitian ini dilakukan di SMA Swasta Al-Hidayah Medan, jalan Letda Sujono, kecamatan Medan Tembung kota Medan. Waktu penelitian yaitu pada semester II tahun pembelajaran 2014/2015.

Populasi dalam penelitian ini adalah semua siswa-siswi kelas XI SMA Swasta Al-Hidayah Medan pada semester genap T.P.2014/2015, yang berjumlah 3 kelas. Dengan menggunakan teknik cluster random sampling, diperoleh sampel dari populasi sebanyak 2 kelas. Kelas eksperimen adalah kelas XI-1 yang diberi perlakuan menggunakan model pembelajaran inkuiri terbimbing (guided inquiry) dan sebagai kelas kontrol adalah kelas XI-2 yang dibelajarkan menggunakan pembelajaran konvensional. Variabel dalam penelitian ini terdiri atas variabel bebas yaitu model pembelajaran inkuiri terbimbing dan pembelajaran konvensional, dan variabel terikat yaitu hasil belajar.
Instrumen yang digunakan adalah tes pilihan ganda yang terdiri atas 20 soal dan lembar observasi untuk mengetahui aktivitas belajar siswa. Soal tes yang digunakan terlebih dahulu dilakukan validasi isi dan validasi ramalan. Analisis yang digunakan adalah uji hipotesis (Uji t) dengan taraf signifikan $\alpha=0,05$. Uji $t$ terlebih dahulu dilakukan uji prasyarat yaitu uji normalitas dan uji homogenitas.

\section{HASIL DAN PEMBAHASAN Hasil Penelitian}

Adapun hasil belajar siswa sebelum diberi perlakuan dapat dilihat pada ringkasan tabel.1 berikut:

Tabel 1. Ringkasan Data Pretes Kelas Eksperimen dan Kelas Kontrol

\begin{tabular}{|l|l|l|l|}
\hline No. & \multicolumn{1}{|c|}{$\begin{array}{c}\text { Jenis } \\
\text { Perlakuan }\end{array}$} & $\begin{array}{c}\text { Rata- } \\
\text { rata }\end{array}$ & $\begin{array}{c}\text { Simpangan } \\
\text { baku }\end{array}$ \\
\hline 1. & $\begin{array}{l}\text { Kelas } \\
\text { Eksperimen }\end{array}$ & 28,70 & 10,43 \\
\hline 2. & $\begin{array}{l}\text { Kelas } \\
\text { Kontrol }\end{array}$ & 27,78 & 9,98 \\
\hline
\end{tabular}

Ringkasan uji normalitas dan homogenitas pretes kelas eksperimen dan kelas kontrol dapat dilihat pada tabel.2 berikut:

Tabel 2. Ringkasan hasil perhitungan uji normalitas dan homogenitas data pretes kelas eksperimen dan kontrol

\begin{tabular}{|c|c|c|c|c|c|c|}
\hline \multirow{2}{*}{$\begin{array}{c}\text { Kel } \\
\text { as }\end{array}$} & \multicolumn{2}{|c|}{ Data pretes } & \multirow{2}{*}{$\begin{array}{l}\text { Kes } \\
\text { imp } \\
\text { ulan }\end{array}$} & \multicolumn{2}{|c|}{$\begin{array}{c}\text { Data } \\
\text { pretes }\end{array}$} & \multirow{2}{*}{$\begin{array}{c}\text { kesi } \\
\text { mp } \\
\text { ulan }\end{array}$} \\
\hline & $\begin{array}{l}\mathrm{L}_{\text {hitu }} \\
\mathrm{ng}\end{array}$ & $\overline{\mathrm{L}_{\text {tabel }}}$ & & $\begin{array}{l}\mathrm{F}_{\mathrm{hi}} \\
\text { tung }\end{array}$ & $\begin{array}{l}\mathrm{F}_{\mathrm{ta}} \\
\text { bel }\end{array}$ & \\
\hline $\begin{array}{l}\text { Eks } \\
\text { peri } \\
\text { men }\end{array}$ & $\begin{array}{r}0,08 \\
90\end{array}$ & $\begin{array}{r}0,1 \\
680\end{array}$ & $\begin{array}{l}\text { Nor } \\
\text { mal }\end{array}$ & \multirow[t]{2}{*}{$\begin{array}{c}1, \\
21\end{array}$} & \multirow[t]{2}{*}{$\begin{array}{r}1, \\
93\end{array}$} & \multirow{2}{*}{$\begin{array}{l}\text { Ho } \\
\text { mo } \\
\text { gen }\end{array}$} \\
\hline $\begin{array}{l}\text { Kon } \\
\text { trol }\end{array}$ & $\begin{array}{r}0,12 \\
37\end{array}$ & $\begin{array}{r}0,1 \\
680\end{array}$ & $\begin{array}{l}\text { Nor } \\
\text { mal }\end{array}$ & & & \\
\hline
\end{tabular}

Setelah dilakukan uji normalitas dan uji homogenitas, selanjutnya adalah menguji hipotesis.

Ringkasan uji kesamaan rata-rata pretes ditunjukkan pada Tabel 3.

Tabel 3.Ringkasan Perhitungan Uji t pretes

\begin{tabular}{|c|c|c|c|c|}
\hline Data & $\begin{array}{c}\text { Rat } \\
\text { a- } \\
\text { rata }\end{array}$ & thitung & $\mathrm{t}_{\text {tabel }}$ & $\begin{array}{c}\text { Kesimpu } \\
\text { lan }\end{array}$ \\
\hline Pretes & 28,7 & 0,33 & 2,00 & Kemamp \\
\hline
\end{tabular}




\begin{tabular}{|c|c|c|c|}
\hline $\begin{array}{l}\text { kelas } \\
\text { eskperim } \\
\text { en }\end{array}$ & 0 & & $\begin{array}{l}\text { uan awal } \\
\text { siswa } \\
\text { pada }\end{array}$ \\
\hline $\begin{array}{l}\text { Pretes } \\
\text { kelas } \\
\text { kontrol }\end{array}$ & $\begin{array}{r}27,7 \\
8\end{array}$ & 8 & $\begin{array}{l}\text { kedua } \\
\text { kelompo } \\
\text { k sampel } \\
\text { sama }\end{array}$ \\
\hline
\end{tabular}

Berdasarkan Tabel $3 t_{\text {hitung }}<t_{\text {tabel }}$ yang berarti kemampuan awalsiswa kedua kelas atau kelompok sampel adalah sama.

Setelah selesai melakukan pretes, kemudian kedua sampel diberikan perlakuan yang berbeda yaitu model pembelajaran inkuiri terbimbing pada siswa kelas eksperimen dan pembelajaran konvensional pada siswa kelas kontrol. Dimana pada proses pembelajaran berlangsung, peneliti mengamati aktivitas belajar siswa melalui lembar observasi. Hasil aktivitas belajar siswa dapat dilihat pada tabel 4 berikut:

Tabel 4. Nilai Rata-Rata Aktivitas Siswa

\begin{tabular}{|c|c|c|c|}
\hline Sampel & $\begin{array}{l}\text { Pertemuan } \\
\text { ke- }\end{array}$ & $\begin{array}{l}\text { Nilai } \\
\text { Akhir }\end{array}$ & $\begin{array}{l}\text { Nilai } \\
\text { Rata- } \\
\text { Rata }\end{array}$ \\
\hline \multirow{3}{*}{$\begin{array}{c}\text { Kelas } \\
\text { Eksperimen }\end{array}$} & I & 72,66 & \multirow{3}{*}{77,89} \\
\hline & II & 79,89 & \\
\hline & III & 81,13 & \\
\hline \multirow{3}{*}{$\begin{array}{l}\text { Kelas } \\
\text { Kontrol }\end{array}$} & I & 54,32 & \multirow{3}{*}{59,761} \\
\hline & II & 61,20 & \\
\hline & III & 63,32 & \\
\hline
\end{tabular}

$$
\text { Setelah selesai memberikan }
$$

pembelajaran pada kelas eksperimen dan kontrol, kedua kelas selanjutnya diberikan postes dengan soal yang sama untuk mengetahui perbedaan hasil belajar siswa. Hasil belajar postes dapat dilihat pada tabel.5 berikut:

Tabel 5.Ringkasan Data Postes Kelas Eksperimen dan Kontrol

\begin{tabular}{|l|l|l|l|}
\hline No & $\begin{array}{l}\text { Jenis } \\
\text { Perlakuan }\end{array}$ & Rata-rata & $\begin{array}{l}\text { Simpangan } \\
\text { baku }\end{array}$ \\
\hline 1. & $\begin{array}{l}\text { Kelas } \\
\text { Eksperimen }\end{array}$ & 71,67 & 11,44 \\
\hline 2. & $\begin{array}{l}\text { Kelas } \\
\text { Kontrol }\end{array}$ & 62,22 & 10,41 \\
\hline
\end{tabular}

Ringkasan uji normalitas dan homogenitas data postes kelas eksperimen dan kontrol ditunjukkan pada tabel 6 .

Tabel 6. Ringkasan hasil perhitungan uji normalitas dan homogenitas data

\begin{tabular}{|c|c|c|c|c|c|c|}
\hline \multirow[b]{2}{*}{ Kelas } & \multicolumn{2}{|c|}{$\begin{array}{c}\text { Data } \\
\text { postes }\end{array}$} & \multirow{2}{*}{$\begin{array}{l}\mathrm{K} \\
\text { es } \\
\mathrm{im} \\
\mathrm{pu} \\
\mathrm{la} \\
\mathrm{n}\end{array}$} & \multicolumn{2}{|c|}{$\begin{array}{l}\text { Data } \\
\text { pretes }\end{array}$} & \multirow[b]{2}{*}{$\begin{array}{c}\text { kesi } \\
\text { mpu } \\
\text { lan }\end{array}$} \\
\hline & $\begin{array}{l}\mathrm{L}_{\text {hitu }} \\
\mathrm{ng}\end{array}$ & $\mathrm{L}_{\text {tabel }}$ & & $\begin{array}{l}\mathrm{F}_{\text {hi }} \\
\text { tung }\end{array}$ & $\begin{array}{l}\mathrm{F}_{\mathrm{ta}} \\
\text { bel }\end{array}$ & \\
\hline $\begin{array}{l}\text { Eksperi } \\
\text { men }\end{array}$ & $\begin{array}{r}0,12 \\
16\end{array}$ & $\begin{array}{r}0,16 \\
82\end{array}$ & $\begin{array}{l}\mathrm{N} \\
\text { or } \\
\mathrm{m} \\
\mathrm{al}\end{array}$ & \multirow{2}{*}{$\begin{array}{l}1, \\
21\end{array}$} & \multirow{2}{*}{$\begin{array}{c}1, \\
93\end{array}$} & \multirow{2}{*}{$\begin{array}{l}\text { Ho } \\
\text { mo } \\
\text { gen }\end{array}$} \\
\hline Kontrol & $\begin{array}{r}0,16 \\
23\end{array}$ & $\begin{array}{r}0,16 \\
82\end{array}$ & $\begin{array}{l}\mathrm{N} \\
\text { or } \\
\mathrm{m} \\
\mathrm{al}\end{array}$ & & & \\
\hline
\end{tabular}

Hal sama juga dilakukan di postes, yaitu menguji hipotesis. Dimana uji hipotesis yang digunakan pada postes adalah Uji t satu pihak yang digunakan untuk mengetahui adanya pengaruh dari suatu perlakuan yaitu model pembelajaran Krinkkiairi terhadap hasil belajar siswa. Ringkasan hasil uji $\mathrm{t}$ ditunjukkan pada Tabel 7.

Tabel 7. Ringkasan Perhitungan Uji $t$

\begin{tabular}{|c|c|c|c|c|}
\hline \multicolumn{5}{|c|}{ Postes } \\
\hline Cukup Data & $\begin{array}{c}\text { Rata- } \\
\text { rata }\end{array}$ & $\begin{array}{c}\mathrm{t}_{\text {hitun }} \\
\mathrm{g}\end{array}$ & $\mathrm{t}_{\text {tabel }}$ & $\begin{array}{c}\text { Kesimpula } \\
\mathrm{n}\end{array}$ \\
\hline $\begin{array}{l}\text { Postes } \\
\text { kelas } \\
\text { eskperi } \\
\text { men }\end{array}$ & 71,67 & & & $\begin{array}{l}\text { Hasil } \\
\text { belajar } \\
\text { siswa di } \\
\text { kelas }\end{array}$ \\
\hline $\begin{array}{l}\text { Postes } \\
\text { kelas } \\
\text { Kontrol }\end{array}$ & 62,22 & 181 & 4 & $\begin{array}{l}\mathrm{n} \text { lebih } \\
\text { tinggi } \\
\text { daripada di } \\
\text { kelas } \\
\text { kontrol. }\end{array}$ \\
\hline
\end{tabular}

Berdasarkan analisis data pada Tabel 7, dapat disimpulkan bahwa ada pengaruh yang signifikan model pembelajaran inkuiri terhadap hasil belajar siswa.

\section{Pembahasan Penelitian}

Hasil penelitian menunjukkan, ada pengaruh yang signifikan dari model pembelajaran inkuiri terbimbing terhadap hasil belajar siswa pada materi fluida dinamis di kelas XI SMA Swasta Al Hidayah Medan T.P.2014/2015, yang ditunjukkan dengan hasil nilai rata-rata 
postes di kelas eksperimen sebesar 71,70 dan di kelas kontrol sebesar 62,22.

Hal ini didapat karena dalam pembelajarannya inkuiri terbimbing (guided inquiry), keaktifan dan keterlibatan secara maksimal siswa lebih ditekankan pada proses pembelajaran (Gulo, 2008: 101). Dimana, diawal proses belajarmengajar siswa dihadapkan pada masalah dengan mengajak siswa memperhatikan realitas yang berhubungan dengan konsep. Tujuannya adalah untuk merangsang siswa untuk merumuskan masalah yang selanjutnya menguji hipotesis mereka dengan melakukan kegiatan ilmiah untuk menemukan konsep yang sedang dipelajari. (Bruner dalam Khultau, 2007: 17-18). Aktifitas ilmiah yang dimaksud adalah melakukan eksperimen yang dilengkapi dengan LKS. Dimana penggunaan LKS dapat mengoptimalkan kemampuan berfikir kritis peserta didik (Damayanti, Ngazizah dan Setiadi , 2013: 61).

Pada tahap pertama (orientasi), peneliti menggali kemampuan awal siswa sehingga siswa tertarik dan siap untuk mengikuti pembelajaran. Pada tahap ini guru mengajak siswa untuk memperhatikan realitas atau pengalaman yang berhubungan dengan konsep yang akan dipelajari serta menstimulus siswa dengan memberikan pertanyaan yang berhubungan dengan konsep. Karena dengan pengalaman itulah setiap individu akan dapat membangun pengetahuan yang berguna bagi diri dan masyarakatnya (Sanjaya, 2011: 202). Pada pertemuan I sudah ada siswa yang mejawab pertanyaan yang diajukan peneliti walaupun hanya beberapa orang. Memasuki pertemuan ke II dan ke III jumlah siswa yang memberikan jawaban semakin meningkat.

Tahap kedua (eksplorasi), siswa menyusun hubungan antar masalah, kemudian peneliti mengorganisasikan dan membagikan setiap kelompok sebuah Lembar Kerja Siswa (LKS). Masingmasing kelompok kemudian diminta membuat hipotesis terhadap masalah yang dihadapkan pada tahap sebelumnya. Setelah itu, siswa mengajukan pertanyaan. Selanjutnya pada tahap ketiga yaitu mengidentifikasi masalah dalam penyelidikan, setiap kelompok bereksperimen sesuai dengan prosedur yang ada di LKS, untuk mendapatkan data dengan menggunakan alat dan bahan yang telah disediakan peneliti. Setelah selesai melakukan percobaan, kemudian setiap kelompok menganalisis data untuk membangun penjelasan. Sesuai dengan dukungan pernyataan Dimyati dan Mudjiono, belajar yang paling baik adalah bukan hanya sekedar mengamati secara langsung tetapi ia harus menghayati, terlibat langsung dalam perbuatan, dan bertanggung jawab dalam hasilnya.

Tahap keempat dan kelima (pembentukan konsep dan aplikasi), dalam tahap ini siswa dengan masing-masing kelompoknya melakukan diskusi. Setiap siswa dari masing-masing kelompoknya diberikan kesempatan untuk memaparkan hasil eksperimennya. Pada tahap ini, terjadi juga sesi tanya jawab antar kelompok yang dibimbing oleh peneliti. Pada tahap inilah keefisienan waktu sangat diperlukan, sebab menurut pengalaman peneliti pada saat tahap ini hampir semua kelompok masih tidak tau mengenai tugas eksperimen mereka (terlebih pertemuan sebelumnya. Hal tersebut menimbulkan banyak pertanyaan siswa kepada peneliti, dan membutuhkan bimbingan serta waktu yang lebih banyak. Tahap terakhir (evaluasi), menyusun teori pendukung dalam upaya mengatasi kesulitan guru dan siswa serta menyimpulkan pembelajaran dengan mengevaluasi proses pembelajaran yang sudah dilaksanakan serta hasil belajar yang sudah didapat.

Pada kelas kontrol, peneliti menerapkan metode pembelajaran yang sama seperti yang dilakukan oleh guru yang mengajar di kelas tersebut. Peneliti menjelaskan materi pelajaran dan mencatatkan di papan tulis, memberi contoh soal, memberi tugas dan latihan, kemudian meminta siswa yang mampu atau menunjuk langsung siswa menjawab soal latihan dan 
menuliskannya di papan tulis. Singkatnya, aktivitas yang dilakukan siswa pada kelas ini tidak menuntut siswa untuk terlibat langsung dengan kegiatan-kegiatan yang menekankan proses pemahaman berdasarkan penyelidikan ilmiah (Dimyati dan Mudjiono, 2010: 45-46). Dengan kata lain, guru lebih banyak mengambil peran dalam pembelajaran di kelas kontrol (teacher centered).

Penilaian aktivitas belajar pada kelas eksperimen dan kelas kontrol dibuat sama guna melihat perbedaan dari berbagai aspek yang dianggap berdampak terhadap hasil belajar mereka. Aspek-aspek penilaian yang digunakan untuk mengukur tingkat aktivitas siswa pada kelas eksperimen dan kontrol memberi gambaran yang cukup signifikan tentang bagaimana data berbicara banyak dalam meningkatkan hasil belajar siswa. Hal ini tampak dari data yang menunjukkan perbedaan rata-rata aktivitas siswa dimana siswa pada kelas eksperimen mendominasi dengan rata-rata 77,89 yang tergolong aktif sedangkan pada kelas kontrol dengan ratarata 59,761 dan tergolong cukup. Kelas eksperimen mendominasi perolehan poin dari Motor (Melakukan Percobaan), Mental (Mengolah data dan menjawab pertanyaan),dan Emotional (Semangat dan serius). Hal ini pada gilirannya dapat menjadikan mereka sebagai ilmuan, yang tentunya menjadi keunggulan dalam pembelajaran inkuiri terbimbing sendiri. Dalam hal ini, kelas kontrol bahkan tidak memiliki peluang untuk bisa berkembang dalam aspek tersebut.

Setelah semua materi pembelajaran dan penilaian aktivitas pada kedua kelas dilakukan, selanjutnya adalah memberikan postes kepada keduanya yaitu kelas eksperimen dan kelas kontrol. Dari hasil postes yang diperoleh, hasil rata-rata kelas eksperimen adalah 71,67 dengan kriteria penilaian tidak tuntas dan kelas kontrol adalah 62,22 dengan kategori tidak tuntas. Namun jika dibandingkan dengan persentase jumlah siswa yang belum mencapai KKM tersebut lebih kecil dari pada persentase jumlah siswa tidak lulus yang diajar menggunakan pembelajaran konvensional, seperti yang dinyatakan peneliti berdasarkan hasil ulangan fisika siswa pada latar belakang masalah, dengan persentase lebih dari $63 \%$ jumlah siswa. Berarti terjadi peningkatan sekitar $15 \%$ untuk jumlah siswa yang lulus berdasarkan KKM di sekolah tersebut.

Kemudian jika ditinjau dari soal yang terjawab siswa, tidak terdapat soal yang sulit untuk di kelas eksperimen. Namun terdapat satu soal yang sulit di kelas kontrol yaitu soal nomor 15 yang merupakan jenis ranah kognitif C3. Dimana hanya $22,22 \%$ siswa yang menjawab benar. Hal ini merupakan kelemahan dari peneliti sendiri karena untuk materi tabung pitot di kelas kontrol terlewatkan disebabkan waktu yang kurang memadai.

Selama pelaksanaan penelitian diperoleh bahwa model pembelajaran inkuiri terbimbing dapat meningkatkan hasil belajar siswa dan aktifitas siswa. Hal ini didukung dengan pernyataan Mayer dalam Arends yaitu dalam pembelajaran inkuiri terbimbing siswa belajar lebih baik ketika mereka aktif (Arend, 2012: 341342). Penelitian relevan lainnya menyatakan bahwa model pembelajaran berbasis inkuiri memiliki efek positif terhadap perkembangan prestasi belajar (Avsec dan Kocijancic, 2014: 329); siswa dalam kelompok eksperimen memiliki pemahaman yang lebih baik dan mendasarkan konsep dan sikap yang lebih positif terhadap instruksi inkuiri terbimbing (Bilgin, 2009: 1); siswa yang diperintahkan melalui pembelajaran berbasis penyelidikan dicapai skor yang lebih tinggi daripada yang diinstruksikan malalui metode tradisional (Abdi, 2014: 37); terdapat pengaruh penerapan model inkuiri terbimbing terhadap kemampuan berfikir logis siswa kelas X di SMA Negeri 8 kota Bengkulu (Purwanto, 2013: 249); kumpulan situs web penyelidikan-pelatihan sederhana seragam, dan efektif untuk siswa sekolah dasar dan menengah. Serta informasi yang disajikan dapat diterapkan untuk bidang studi lain juga (Gillani: 2010: 1); dan model 
pembelajaran inkuiri terbimbing dapat meningkatkan hasil belajar (Wahyudi dan Supardi, 2013: 1).

Walaupun penggunaan model pembelajaran inkuiri dapat meningkatkan hasil belajar dan aktivitas belajar siswa dibandingkan dengan pembelajaran konvensional, tetapi selama proses pembelajaran banyak kendala yang dihadapi yaitu kurangnya penguasaan kelas dan manajemen waktu yang belum tepat dalam proses pembelajaran serta sebagian siswa masih ada yang bingung dan kurang serius dalam belajar menggunakan model pembelajaran inkuiri terbimbing karena model ini belum pernah diterapkan disekolah tersebut. Setelah dilakukan analisis, menurut teori pembelajaran inkuiri, model inkuiri akan kurang berhasil jika diterapkan pada siswa yang kurang memiliki kemauan dan kemampuan berpikir. Seperti yang dinyatakan oleh Ngalimun bahwa model pembelajaran inkuiri memerlukan jumlah pelajaran kelas yang banyak dan waktu di luar kelas dibandingkan dengan model pembelajaran lainnya serta memerlukan proses mental yang berbeda seperti perangkat analitik dan kognitif (Ngalimun, 2014: 41). Yamin menambahkan metode-metode inkuiri tidak efektif dan bahkan detrimental untuk peserta didik berkemampuan lebih rendah (Yamin, 2013: 76). Selain itu juga terdapat kelemahan peneliti sendiri yang kurang menguasai sintak model pembelajaran inkuiri terbimbing. Hal tersebut mungkin akan berbeda jika peneliti memahami dan menguasai sintak inkuiri terbimbing itu sendiri dan menerapkannya pada kelompok siswa yang memiliki kemauan dan kemampuan berpikir.

Kelemahan lain dari penelitian ini adalah ada terdapat soal yang materinya terlewatkan, yang menyebabkan siswa tidak mampu menjawabnya. Untuk itu perbaikan bagi peneliti selanjutnya agar memperhatikan ataupun mempersiapkan instrumen yang memang benar-benar dibahas dalam pembelajaran tersebut.

\section{PENUTUP}

\section{Kesimpulan}

Setelah melakukan penelitian, perhitungan dan analisis data, berdasarkan analisis uji hipotesis dapat disimpulkan ada pengaruh yang signifikan model pembelajaran inkuiri terbimbing (Guided Inquiry) terhadap hasil belajar siswa pada materi fluida dinamis di kelas XI SMASwasta Al Hidayah Medan T.P.2014/2015.

\section{Saran}

Berdasarkan hasil dan kesimpulan dalam penelitian ini, maka penulis menyampaikan saran sebagai yaitu kepada peneliti, guru dan calon guru yang ingin menggunakan model pembelajaran inkuiri terbimbing (guided inquiry) hendaknya menyusun RPP yang lebih baik, instrumen sesuai dengan materi diajarkan dan menguasai semua sintak mengenai model pembelajaran inkuiri. Bagi para peneliti selanjutnya yang ingin meneliti tentang model pembelajaran inkuiri lebih lanjut agar menggunakan waktu seefisien dan menerapkan model pembelajaran tersebut pada siswa yang memiliki kemauan dan kemampuan berpikir. Hal tersebut agar tujuan yang diharapkan sesuai teori pembelajaran inkuiri dapat tercapai dengan efektif.

\section{DAFTAR PUSTAKA}

Abdi, Ali, (2014), The Effect of Inquirybased Learning Method on Students' Academic Achievement in Science Course, Universal Journal of Educational Research 01 : 37-41.

Arends, Richard. I., (2013), Belajar untuk Mengajar, Penerbit Salemba Humanika, Jakarta.

Avsec, S., \& Slavko K., (2014), The effect of the use of an inquiry-based approach in an open learning middle Stanislav Avsec \& Slavko Kocijancic, World Transactions on Engineering and Technology Education 12: 1-9.

Bilgin, Ibrahim, (2009), The effects of guided inquiry instruction 
incorporating a cooperative learning approach on university students' achievement of acid and bases concepts and attitude toward guided inquiry instruction, Academic Journals 04: 1-9.

Damyanti, Dyah Shinta, Nur Ngazizah dan Eko Setyadi K., (2013), Pengembangan Lembar Kerja Siswa (LKS) dengan Pndekatan Inkuiri Terbimbing untuk Mengoptimalkan Kemampuan Berfikir Krtitis Peserta Didik pada Materi Listrik Dinamis SMA Negeri 3 Purworejo Kelas X Tahun 2012/2013, Radiasi 03: 59-62.

Dimyati dan Mudjiono, (2002), Belajar dan Mengajar, Jakarta, Rineka Cipta.

Gillani, Bijan B., (2010), Inquiry-Based Training Model and the Design of ELearning Environments, Issues in Informing Science and Information Technologi 07: 1-8.

Hamalik, Oemar, (2001), Proses Belajar Mengajar, Penerbit Bumi Aksara, Bandung.

Harahap, A.R., (2014), Pengaruh Model Pembelajaran Inkuiri Terhadap Hasil Belajar Fisika Siswa pada Materi Pokok Listrik Dinamis di Kelas X SMA Swasta Al Ulum Medan T.P.2013/2014, Jurnal Inpafi 02: 110.

Kuhlthau, C. Carol., Leslie K. Maniotes, dan Ann K. Caspari, (2007). Models Guided Inquiry Learning in The $21^{S T}$ Century, London: Libraries Unlimited.

Kurniawati, I.D.,Wartono, M. Diantoro, (2014), Pengaruh Pembelajaran Inkuiri Terbimbing Integrasi
Peer Instruction Terhadap

Penguasaan Konsep dan

Kemampuan Berpikir Kritis

Siswa, Jurnal Pendidikan Fisika Indonesia 10:36-46.

Ngalimun, (2014), Strategi dan Model Pembelajaran, Penerbit Aswaja Pressindo, Yogyakarta.

Purwanto, Andik, dan Resty Sasmita, (2013), Pembelajaran Fisika Dengan Menerapkan Model Inkuiri Terbimbing Dalam Menumbuhkan Kemampuan Berfikir Logis Siswa di SMA Negeri 8 Bengkulu, Jurnal Pendidikan : 1-5.

Sanjaya Wina, Strategi Pembelajaran Berorientasi Standar Proses

Pendidikan, Jakarta, Prenada Media.

Sudjana, (2005), Metoda Statistika, Penerbit Tarsit, Bandung.

Trianto, (2011), Mendesain Model Pembelajaran Inovatif-Progresif, Penerbit Prenada Media Group, Jakarta.

Yamin, Martinis, (2013), Strategi dan Metode dalam Model Pembelajaran, Penerbit GP Press Group, Jambi.

Wahyudi, dan Imam Supardi, (2013), Penerapan Model Pembelajaran Inkuiri Terbimbing pada Pokok Bahasan Kalor untuk Melatihkan Keterampilan Sains terhadap Hasil Belajar Siswa di SMAN 1 Sumenep, Jurnal Pendidikan Fisika Indonesia 04 : 1-8.

http://indonesiaberkibar.org/id/faktapendidikan (diakses 16 februari 2015) 